\title{
Genetic association study of the P300 endophenotype in schizophrenia
}

Citation for published version (APA):

Decoster, J., De Hert, M., Viechtbauer, W., Nagels, G., Myin-Germeys, I., Peuskens, J., van Os, J., \& van Winkel, R. (2012). Genetic association study of the P300 endophenotype in schizophrenia. Schizophrenia Research, 141(1), 54-59. https://doi.org/10.1016/j.schres.2012.07.018

Document status and date:

Published: 01/10/2012

DOI:

10.1016/j.schres.2012.07.018

Document Version:

Publisher's PDF, also known as Version of record

Document license:

Taverne

Please check the document version of this publication:

- A submitted manuscript is the version of the article upon submission and before peer-review. There can be important differences between the submitted version and the official published version of record.

People interested in the research are advised to contact the author for the final version of the publication, or visit the DOI to the publisher's website.

- The final author version and the galley proof are versions of the publication after peer review.

- The final published version features the final layout of the paper including the volume, issue and page numbers.

Link to publication

\footnotetext{
General rights rights.

- You may freely distribute the URL identifying the publication in the public portal. please follow below link for the End User Agreement:

www.umlib.nl/taverne-license

Take down policy

If you believe that this document breaches copyright please contact us at:

repository@maastrichtuniversity.nl

providing details and we will investigate your claim.
}

Copyright and moral rights for the publications made accessible in the public portal are retained by the authors and/or other copyright owners and it is a condition of accessing publications that users recognise and abide by the legal requirements associated with these

- Users may download and print one copy of any publication from the public portal for the purpose of private study or research.

- You may not further distribute the material or use it for any profit-making activity or commercial gain

If the publication is distributed under the terms of Article $25 \mathrm{fa}$ of the Dutch Copyright Act, indicated by the "Taverne" license above, 


\title{
Genetic association study of the P300 endophenotype in schizophrenia
}

\author{
Jeroen Decoster ${ }^{\mathrm{a}, \mathrm{b}}$, Marc De Hert ${ }^{\mathrm{a}}$, Wolfgang Viechtbauer ${ }^{\mathrm{a}}$, Guy Nagels ${ }^{\mathrm{a}, \mathrm{d}}$, Inez Myin-Germeys ${ }^{\mathrm{b}}$, \\ Jos Peuskens ${ }^{\mathrm{a}}$, Jim van Os ${ }^{\mathrm{b}, \mathrm{c}}$, Ruud van Winkel ${ }^{\mathrm{a}, \mathrm{b}, *}$
}

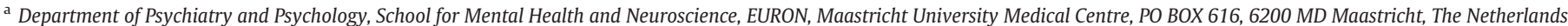

b University Psychiatric Centre Catholic University Louvain, campus Kortenberg, Leuvensesteenweg 517, 3070 Kortenberg, Belgium

c Division of Psychological Medicine, Institute of Psychiatry, De Crespigny Park, London SE5 8AF, United Kingdom

d Service d'orthopédagogie clinique, faculté de psychologie et des sciences de l'éducation, Université de Mons, Place du Parc 18, 7000 Mons, Belgium

\section{A R T I C L E I N F O}

Article history:

Received 29 February 2012

Received in revised form 4 July 2012

Accepted 16 July 2012

Available online 19 August 2012

\section{Keywords:}

Schizophrenia

P300

Event-related potential (ERP)

ABCB1-gene

P-glycoprotein

Intermediate phenotype

\begin{abstract}
A B S T R A C T
Objective: Although reduced amplitude of the P300 event-related potential is a well-documented intermediate phenotype of schizophrenia, little is known about its genetic underpinnings in patients with schizophrenia. This study aims to examine associations between P300 and a range of candidate genetic variants, selected from either candidate gene studies or genome-wide association studies, in a large sample of patients with schizophrenia. Methods: P300 amplitude at the midline parietal electrode and 193 single nucleotide polymorphisms (SNPs) in 67 genes were assessed in 336 patients with schizophrenia. The association between each SNP and P300 amplitude, controlled for illness duration and gender, was evaluated. Associations at $p<.01$ were considered of potential relevance, while Bonferroni correction was applied to determine formal statistical significance (Bonferroni-corrected threshold of significance $p=.0003$ ).

Results: Of the 193 selected SNPs, 4 SNPs showed potentially relevant association with P300 amplitude at a significance level of $p<.01$. One of these SNPs, rs 1045642 in ABCB1, was most convincingly associated with P300 amplitude, reaching formal (Bonferroni-corrected) significance, while there was evidence for possible association with rs1572899 in DISC-1, rs6265 in BDNF and rs1625579 in MIR137.

Conclusion: Genetic variation in ABCB1 may be associated with P300 amplitude in patients with schizophrenia. This result may encourage further efforts to elucidate the genetic underpinnings of P300 generation.
\end{abstract}

(c) 2012 Elsevier B.V. All rights reserved.

\section{Introduction}

The auditory P300 is an event-related potential (ERP) that is typically elicited by an auditory target stimulus serving as the signal for the participant to execute a predefined task, such as pushing a button or counting. It is named after its typical peak $300 \mathrm{~ms}$ after the target stimulus. The P300 is believed to reflect a summation of simultaneous brain processes, including directed attention and contextual updating of working memory (Turetsky et al., 2007; van der Stelt and Belger, 2007). It is described by its amplitude and latency. Two subcomponents can be distinguished: the P3a subcomponent with a predominantly frontal distribution, which reflects the unexpectedness of the stimulus and the P3b subcomponent with a predominantly parietal distribution, reflecting cognitive processing of task-relevant or contextually salient stimuli (Turetsky et al., 2007).

Reduced amplitude of the auditory P300, especially the P3b subcomponent, has been consistently reported in patients with schizophrenia (Turetsky et al., 2007; van der Stelt and Belger, 2007). Although reduced P300 amplitude is not specific to schizophrenia, the observed deficits are distinguishable in several aspects from the P300-deficits in

\footnotetext{
* Corresponding author at: Department of Psychiatry and Psychology, Maastricht University Medical Centre, PO BOX 616 (location VIJV SN2), 6200 MD Maastricht, The Netherlands. Tel.: +31433685 372; fax: + 31433688689 .

E-mail address: ruud.vanwinkel@maastrichtuniversity.nl (R. van Winkel).
}

Alzheimer disease (marked latency prolongation), alcoholism (more visual than auditory abnormalities) and depression (state-dependent abnormalities), suggesting different underlying neural mechanisms (Souza et al., 1995; Salisbury et al., 1999; Turetsky et al., 2007). However, since P300 amplitudes at centro-parietal sites in patients with bipolar disorder manifesting psychotic symptoms were not distinguishable from those of patients with schizophrenia, it was suggested that decreased P300 amplitude at these sites may mark functional psychosis in general (Bestelmeyer et al., 2009).

The heritability of the P300 was established by several twin studies (O'Connor et al., 1994; Bestelmeyer et al., 2009; Hall et al., 2009). Moreover, part of the genetic contribution to the P300 waveform is shared with the genetic contribution to schizophrenia (Hall et al., 2007) and family members of patients with schizophrenia also show significantly reduced P300 amplitudes compared to the general population, although to a lesser degree than their ill relatives (Bramon et al., 2005).

Reduced P300 amplitude was found in first-episode patients, recentonset, chronic patients and even people at ultra-high risk for psychosis (van Beijsterveldt et al., 2001; Umbricht et al., 2006; Turetsky et al., 2007; van der Stelt and Belger, 2007; van Tricht et al., 2011). Given these findings, a decrease in the amplitude of the P300 is commonly accepted as an intermediate phenotype for schizophrenia (Turetsky et al., 2007; van der Stelt and Belger, 2007). 
Although a body of evidence supports reduced P300 amplitude as an intermediate phenotype for schizophrenia, there is limited knowledge of the actual genetic underpinnings of P300 generation in general, and P300 disruption in schizophrenia specifically (Turetsky et al., 2007; van der Stelt and Belger, 2007). Blackwood et al. (2001) reported a reduction of P300 amplitude in a large Scottish family multiply affected with schizophrenia. In this family, a balanced translocation of chromosome 1 and 11, disrupting the DISC1 gene, was strongly associated with both the diagnosis of schizophrenia and reduced P300 amplitude (Blackwood et al., 2001). In addition, reduced P300 amplitude was also observed in unaffected carriers of the translocation (Blackwood et al., 2001). Further studies used a candidate gene approach to examine the association with P300 amplitude in healthy controls (Tsai et al., 2003a; Tsai et al., 2003b; Mulert et al., 2006; Vogel et al., 2006; Gallinat et al., 2007; Schofield et al., 2009; Shaikh et al., 2011), patients with a diagnosis of depression (Chen et al., 2002) or addiction (Johnson et al., 1997; Hill et al., 1998; Berman et al., 2006; Antolin et al., 2009), as well as patients with schizophrenia (Gallinat et al., 2003; Bramon et al., 2006; Golimbet et al., 2006; Bramon et al., 2008; Wang et al., 2009; Shaikh et al., 2011). These studies commonly focused on a single gene, often even limited to a single nucleotide polymorphism (SNP). This is potentially problematic since there are increasing concerns about the candidate gene approach, as the high prevalence of false-positive findings in genetic research may not always be adequately taken into account, especially in the context of undisclosed multiple statistical comparisons (Sullivan, 2007). On the other hand, sample sizes are often too small to allow for the use of genome-wide chips, suggesting that a candidate gene approach with a larger number of SNPs and adequate control for multiple testing may be the most viable option for the research of candidate endophenotypes (Greenwood et al., 2011). Therefore, the current study examined a range of candidate SNPs, selected from either candidate gene studies or genome-wide association studies, in a sample of 336 patients with a schizophrenia spectrum disorder.

\section{Materials and methods}

\subsection{Subjects}

The sample of this study was recruited between October 1999 and November 2006. Psychiatric diagnoses according to DSM-IV criteria were established by experienced psychiatrists affiliated with the University Centre at Louvain, Belgium, and responsible for the patient's treatment. In the University Centre, P300 analysis forms part of a comprehensive neurological and neurophysiological assessment conducted in inpatients, after clinical stabilization. Conform to international guidelines (De Hert et al., 2009), patients receive an elaborate physical health screening including assessment of fasting glucose, lipids and other parameters as described previously (van Winkel et al., 2006; De Hert et al., 2010). On this occasion, they were asked for permission to store a blood sample for genetic analyses and for the anonymous analysis of clinical data recorded during their treatment. The study was approved by the standing ethics committee.

\subsection{P300-recording}

P300 data were recorded using a Neurofax Portable Electroencephalograph EEG-7414 (Nihon Kohden Corporation, Tokyo). During the recording patients were seated in a slightly reclined chair and were asked to fix their gaze at a mark approximately 1 meter in front of them. Evoked responses were recorded with 3 mid-line electrodes ( $F z, C z$ and $\mathrm{Pz}$ ), positioned according to the international $10 / 20$ system and online referenced to left and right ear-electrodes (A1 and A2). Electro-oculogram (EOG) was recorded in order to reject $\mathrm{P} 300$-epochs distorted by eyemovement artefacts. All electrodes were attached with a skin-electrode impedance of less than $5 \mathrm{kOhm}$.
120 sinus tones of $800 \mathrm{~Hz}$ (standard) and 30 sinusoidal tones of $1470 \mathrm{~Hz}$ (deviant), both with a duration of $40 \mathrm{~ms}$ and an intensity of $70 \mathrm{~dB}$ sound pressure level, were presented binaurally through earphones. Each inter-stimulus interval (ISI) was $1 \mathrm{~s}$. Standard and deviant tones were mixed randomly. Patients were asked to push a button as quickly as possible when hearing a deviant tone. Data were collected with a sampling rate of $1024 \mathrm{~Hz}$ and with a high cut-off at $70 \mathrm{~Hz}$. The event-related potentials (ERP) elicited by correctly processed standard (without push on button) and deviant tones (push on button) were averaged separately for each subject, using the EEG epochs from $100 \mathrm{~ms}$ pre-stimulus to $600 \mathrm{~ms}$ post-stimulus. The obtained curves (Fz, Cz, Pz and EOG) were displayed on a LCD-screen and for each electrode the N100 and P300 peaks after the deviant tone were manually indicated. The most negative deflection between $50 \mathrm{~ms}$ and $150 \mathrm{~ms}$ post-stimulus was considered as the $\mathrm{N} 100$, the most positive deflection between $250 \mathrm{~ms}$ and $400 \mathrm{~ms}$ as the P300. The obtained curves and the indicated peak values were printed and the paper report was stored in the patient's file. For 336 patients both DNA and P300 data were available. Because a reduction of P300 amplitude over the midline parietal electrode Pz was described as a very robust finding in patients with schizophrenia (Turetsky et al., 2007; van der Stelt and Belger, 2007), P300 amplitude at $\mathrm{Pz}$ was a priori used for all analyses. During the retrieval of the P300-data, the printed curves were visually inspected. The amplitude of the averaged EOG-curves exceeded the amplitude of the P300-waves in 145 patients. Although EOG-artefacts are not expected to affect measurements at $\mathrm{Pz}$, analysis of the entire sample of 336 patients was complemented with a sensitivity analysis in the sample of 191 patients for whom the averaged EOG curves did not exceed the P300 amplitude.

\subsection{Genetic variation}

A previous study of our group, which examined molecular-genetic interactions with cannabis, selected a total of 179 SNPs, 152 of which passed quality control and were subsequently analyzed (van Winkel and GROUP Investigators, 2011). Gene selection in this study was based on previous evidence of association with schizophrenia, involvement in dopamine or endocannabinoid signaling or an involvement in the regulation of environmental influences including epigenetic mechanisms. Since this selection included the most studied candidate genes for schizophrenia prior to the genome-wide studies, this set was used as the starting point for our SNP selection. This set was updated with 24 SNPs either showing association with schizophrenia at grade ' $\mathrm{A}$ ' or 'B' level in the SzGene database (Allen et al., 2008) (update 26 February 2010) or identified by genome-wide association studies (situated in PGBD1, NRGN, NOTCH4, PDE4B, TCF4, TPH1, HTR2A, RELN, MDGA1, CCKAR, DRD4, APOE, GWAS 11p14.1, PLXNA2, GABRB2, SRR, ANK3, CACNA1C, ZNF804A, MHC, MIR137). Finally, a set of 10 SNPs was selected for intended pharmacogenetic studies (in ABCB1, ADH1C, AS3MT, CYP17A1, CYP1A2, CYP2D6, FOXA2, GSTP1, SOD2). It was decided to also analyze these SNPs in the context of this study, since for one of these SNPs, rs1045642 in ABCB1, an association with P300-amplitude was found in a sample of healthy controls using a data-driven analysis with 384 SNPs in 222 genes, which survived stringent correction for multiple testing (Liu et al., 2009).

The sample used in this article is completely independent of the GROUP sample that was used to examine the molecular-genetic interactions with cannabis (van Winkel and GROUP Investigators, 2011). The sample analyzed here is part of a larger sample (UPC-CUL sample) previously described in the context of metabolic syndrome (van Winkel et al., 2010), which now has been genotyped for the same markers as the GROUP sample with the intention of replication of the moleculargenetic cannabis findings. From the UPC-CUL sample, only the patients for whom a P300 measurement was available $(n=336)$ were included in this current study.

The selected SNPs were determined by Sequenom (Hamburg, Germany) using the MassARRAY iPLEX platform at the facilities of 
the manufacturer; SNPs, therefore, were not selected from a larger set of genomewide markers.

Of the 205 SNPs originally included, (see Supplementary Table S1), 8 SNPs were excluded because they had more than $10 \%$ genotyping failure (rs165599 in COMT, rs1800955 in DRD4, rs2032582 in ABCB1, rs265981 in DRD1, rs3892097 in CYP2D6, rs403636 in SLC6A3, rs6465084 in GRM3 and rs9296158 in FKBP5). 3 SNPs were excluded because of Hardy-Weinberg disequilibrium $(p<.001)$ (rs2023239 in CNR1, rs28362317 in SLC6A3 and rs743572 in CYP17A1) and no variation was found for 1 SNP (rs1799961 in DRD1). Thus, a final set of 193 SNPs in 67 genes was suitable for further analysis.

\subsection{Statistical analyses}

All analyses were conducted using STATA/SE 10.1 for Windows (StataCorp, 2007), regressing continuous P300 amplitude, as dependent variable, on each SNP. Genotypes were coded '0', ' 1 ' or ' 2 ' according to the number of minor alleles and modeled as a linear effect, since this method can deal with different genotype distributions, including distributions with a low minor allele frequency, as it avoids stratification into small subgroups (Cordell and Clayton, 2005). Given the amount of multiple testing involved, associations at $p<.01$ were arbitrarily considered of potential relevance, while Bonferroni correction was applied to determine formal statistical significance (Bonferroni-corrected threshold of significance $p=.0003$ ). Thus, SNPs that reached $p<.01$ significance in the main analysis were also analyzed in the sample of 191 patients with a P300 measurement surpassing the most stringent quality control as a sensitivity analysis to maximize the signal to noise ratio, however at the cost of reduced statistical power. All P300 values differing more than 3 standard deviations from the mean were considered as outliers and excluded from the regression analyses ( $n=4$ in the main analysis, $n=1$ in the sensitivity analysis), as recommended by Osborne and Overbay (2004). Analyses were controlled for the a priori defined confounders illness duration and gender.

A statistical power calculation was performed for the total sample as well as for the sensitivity analysis. In the total sample, this study has a power of $100 \%$ to detect a SNP that explains $10 \%$ of the variation in P300 amplitude according to the used regression model (with $\alpha=.01$ ), $95 \%$ to detect a SNP accounting for $5 \%$ and $53 \%$ to detect a SNP accounting for $2 \%$ of the P300 variation. In the sensitivity analyses, the power decreases to $98 \%, 74 \%$ and $29 \%$, respectively.

\section{Results}

\subsection{Sample}

The sample consisted of 336 individuals with a psychotic disorder who were on average 32.6 years old (SD 11.0, range 14.4-64.2) and of whom $68.5 \%$ were male. The average illness duration was 8.5 year (SD 9.6, range 0-42). Patients had clinical diagnoses of schizophrenia (64.3\%), schizophreniform disorder $(12.2 \%)$ or schizoaffective disorder (23.5\%). For the sensitivity analysis, 191 individuals were included with an average age of 31.3 years (SD 10.2, range 14.4-57.1), $74.4 \%$ were male. The average illness duration was 7.6 year (SD 8.8, range $0-34$ ), also with clinical diagnoses of schizophrenia (67.0\%), schizophreniform disorder $(8.4 \%)$ or schizoaffective disorder $(24.6 \%)$ (see Table 1 for more details). Because of the significant differences in diagnosis, Clinical Global Impression (CGI) scale and Global Assessment of Functioning (GAF) score, those three variables were added as possible confounders in the regression model of the sensitivity analysis.

\section{2. $P 300$}

The overall mean P300 amplitude at Pz was $13.2 \mu \mathrm{V}$ (SD 6.4; range -.4 to 48.8 ). Four outliers were excluded from the analyses, resulting in a corrected average of $12.9 \mu \mathrm{V}$ (SD 5.6; range -.4 to
Table 1

Epidemiological and clinical information of the total sample and the sensitivity analysis subsample.

\begin{tabular}{|c|c|c|c|}
\hline & \multirow{2}{*}{$\frac{\text { Total sample }}{(n=332)}$} & \multirow{2}{*}{$\frac{\text { Sensitivity analysis }}{(n=190)}$} & \multirow[t]{2}{*}{$p^{\mathrm{a}}$} \\
\hline & & & \\
\hline Male (\%) & $230(68.5 \%)$ & $142(74.4 \%)$ & .010 \\
\hline Mean age (SD) & $32.4(11.0)$ & $31.3(10.2)$ & .030 \\
\hline Age range & $14.4-64.2$ & $14.4-57.1$ & \\
\hline DSM-IV diagnosis & & & .039 \\
\hline Schizophrenia & $216(64.3 \%)$ & $128(67.0 \%)$ & \\
\hline Schizophreniform disorder & $41(12.2 \%)$ & $16(8.4 \%)$ & \\
\hline Schizo-affective disorder & $79(23.5 \%)$ & $47(24.6 \%)$ & \\
\hline Illness duration in years (SD) & $8.5(9.6)$ & $7.6(8.8)$ & .092 \\
\hline \multicolumn{4}{|l|}{ Antipsychotic medication b } \\
\hline Fenothiazines & $22(8.8 \%)$ & $11(8.1 \%)$ & .776 \\
\hline Thioxanthenes & $46(18.47 \%)$ & $24(17.7 \%)$ & .633 \\
\hline Butyrophenones & $28(11.2 \%)$ & $21(15.4 \%)$ & .026 \\
\hline Diphenylbutylpiperidine & $2(0.8 \%)$ & $1(0.7 \%)$ & .879 \\
\hline Amisulpride & $22(8.8 \%)$ & $14(10.3 \%)$ & .411 \\
\hline Aripiprazole & $5(2.0 \%)$ & $1(0.7 \%)$ & .219 \\
\hline Clozapine & $25(10.0 \%)$ & $13(9.6 \%)$ & .724 \\
\hline olanzapine & $76(30.5 \%)$ & $43(31.6 \%)$ & .888 \\
\hline Quetiapine & $27(10.8 \%)$ & $13(9.6 \%)$ & .724 \\
\hline Risperidone & $88(36.1 \%)$ & $49(36.0 \%)$ & .933 \\
\hline Cannabis use & & & .489 \\
\hline Non-user & $196(59.2 \%)$ & $110(57.9 \%)$ & \\
\hline User, outside heaviest period & $115(34.7 \%)$ & $66(34.7 \%)$ & \\
\hline User, during heaviest period & $20(6.0 \%)$ & $14(7.3 \%)$ & \\
\hline CGI (SD) & $4.3(0.8)$ & $4.1(0.7)$ & $<.001$ \\
\hline GAF (SD) & $57.6(11.1)$ & $60.0(9.0)$ & $<.001$ \\
\hline
\end{tabular}

Chi-squared test for categorical variables, double-sided paired $t$-test for continuous variables.

$\mathrm{SD}=$ standard deviation $/ \mathrm{CGI}=$ clinical global impression (scale form $1-7) / \mathrm{GAF}=$ global assessment of functioning.

${ }^{a} p$-Values of statistical comparison between patients in sensitivity analyses and those who were dropped on the basis of EOG artefacts.

b Data available for 249 patients (74.1\%) of the total sample, of whom $136(71.2 \%)$ in the sensitivity analysis.

32.4). P300 amplitude was significantly associated with illness duration (Coef $=-.107 ; 95 \%-\mathrm{Cl}:-.170$ to $-.044 ; p=.001)$, but not with gender (Coef $=-.478 ; 95 \%-C I:-1.794$ to $.837 ; p=.475$ ). Four SNPs showed an association with P300 amplitude at $p<.01$; situated in ABCB1, MIR137, BDNF and DISC-1 (Table 2). The sensitivity analysis supported an association with P300 amplitude for rs1045642 in ABCB1 (reaching Bonferroni-corrected statistical significance), and to a lesser degree for rs1572899 in DISC-1 and for rs6265 in BDNF, but not for rs1625579 in MIR137 (Table 2). Patients homozygous for the C-allele of rs1045642 $(n=76)$ had an average P300 amplitude of $11.4 \mu \mathrm{V}(\mathrm{SD} 5.1 \mu \mathrm{V})$ versus $12.8 \mu \mathrm{V}(\mathrm{SD} 5.8 \mu \mathrm{V})$ in heterozygous patients $(n=167)$ and $14.4 \mu \mathrm{V}$ (SD $5.6 \mu \mathrm{V}$ ) in patients with the T/T genotype $(n=89)$ (Fig. 1$)$. A QQ-plot of the residuals of the regression model indicated no departure from normality.

\subsection{Follow-up analyses of the $A B C B 1$ finding}

The ABCB1-gene, formerly called Multi Drug Resistance 1 (MDR1) gene, encodes for the P-glycoprotein that has a known function in ATP-driven cellular excretion of a wide range of exogenous and endogenous substrates, like drugs, hormones (Moons et al., 2011) and tetrahydrocannabinol (THC) (Bonhomme-Faivre et al., 2008). Therefore, post-hoc analyses examined possible confounding of the association between P300 and ABCB1 by antipsychotic medication and cannabis use.

None of the different classes of antipsychotics was significantly associated with P300 amplitude (Table 3). Moreover, when covarying for type of antipsychotic, the association between rs1045642 in $\mathrm{ABCB} 1$ and $\mathrm{P} 300$ amplitude remained significant $($ Coef $=-1.822$; 95\%-CI: -2.826 to $-.818 ; p=.00042$ ).

Lifetime cannabis use was assessed using the Composite International Diagnostic Interview (CIDI)-lifetime section on substance 
Table 2

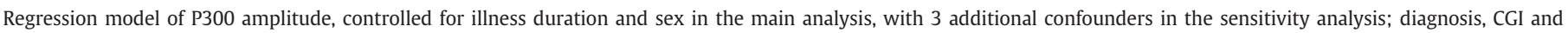

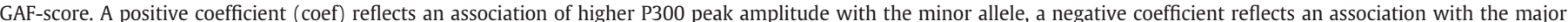

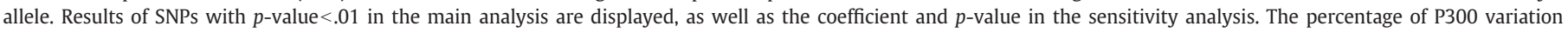
explained (EV) by adding the SNP in the significant models, is also reported.

\begin{tabular}{|c|c|c|c|c|c|c|c|c|}
\hline SNP & gene & coef main analysis & 95\%-confidence interval & $p$-value main analysis & $\mathrm{EV}, \%$ & coef sensitivity analysis & $p$-value sensitivity analysis & $\mathrm{EV}, \%$ \\
\hline rs1045642 & ABCB1 & -1.37 & -2.15 to -0.59 & 0.0021 & 2.9 & -2.01 & 0.00017 & 7.0 \\
\hline rs1625579 & MIR137 & 1.70 & $.52-2.88$ & 0.0048 & 2.0 & .91 & 0.2215 & \\
\hline rs6265 & BDNF & -1.47 & -2.53 to -0.41 & 0.0068 & 2.6 & -1.61 & 0.0265 & 2.5 \\
\hline rs1572899 & DISC-1 & -1.26 & -2.19 to -0.34 & 0.0076 & 2.2 & -1.56 & 0.0242 & 2.7 \\
\hline
\end{tabular}

abuse. Patients were thus identified as non-users ( $n=196)$, users with P300-measurement outside the period of heaviest use $(n=116)$ and users with P300-measurement during the period of heaviest use $(n=20)$. There was no significant association between cannabis use and P300 (Coef $=.712$; 95\%-CI: -.290 to $1.714 ; p=.163$ ) and controlling for lifetime cannabis use did not reduce the association between rs1045642 in ABCB1 and P300 amplitude (Coef $=-1.469$; 95\%-CI: -2.322 to $-.616 ; p=.00079)$.

\section{Discussion}

Previous research, as reviewed by Turetsky (Turetsky et al., 2007) and van der Stelt (van der Stelt and Belger, 2007), supports the reliability of reduced P300 amplitude as intermediate phenotype for schizophrenia. Nevertheless, the knowledge of the genetic underpinnings of P300 generation in schizophrenia is limited. This study examined a range of 193 candidate SNPs for their association with $\mathrm{P} 300$ amplitude in 336 patients with schizophrenia.

Of the 193 selected SNPs, 4 SNPs showed potentially relevant association with P300 amplitude at a significance level of $p<.01$, situated in ABCB1, DISC-1, BDNF and MIR137. One of these SNPs, rs1045642 in ABCB1, was most convincingly associated with P300 amplitude, while there was modest evidence for rs1572899 in DISC-1 and rs6265 in BDNF. The association between P300 amplitude and the novel genome-wide supported risk variant rs1625579 in MIR137 was not supported in the sensitivity analysis.

The ABCB1 finding is in line with the results of Liu and colleagues (Liu et al., 2009), who used a parallel independent component analysis of electrophysiological and genetic data (384 SNPs) in order to investigate the genetic underpinnings of auditory ERP components in a sample of healthy individuals. They found the exact same SNP in ABCB1 (rs1045642), which encodes for P-glycoprotein, to be associated with P300 amplitude. The fact that two studies in different samples, one in healthy volunteers and one in patients with schizophrenia, identify the same SNP from a set of hundreds of markers at the Bonferroni-corrected threshold of significance, makes it unlikely that this is a chance finding.

P-glycoprotein has a known function in ATP-driven cellular excretion of, among others, drugs (Moons et al., 2011) and THC (Bonhomme-Faivre et al., 2008). Although rs1045642 is a synonymous polymorphism, it changes the substrate specificity of the translated protein (KimchiSarfaty et al., 2007) and can thus be considered functional. Little is known about the specific influence of the polymorphism on the cellular excretion of different substrates, like antipsychotic drugs and THC. However, post-hoc analyses in the present study, controlling for type of used antipsychotic drug, could not explain the association between rs1045642 and P300 amplitude. This is in line with expectations, since Liu et al. (2009) found the same genotype-phenotype association in healthy individuals, free of antipsychotic drugs. Similarly, controlling for cannabis did not reduce the association between rs1045642 in ABCB1 and P300 amplitude, indicating that the association is unlikely to be mediated by genetically determined differences in P-glycoprotein excretion of THC. The underlying biology of the strong genotype-phenotype association between rs1045642 and P300 amplitude, as well as the specific significance for schizophrenia, remains to be elucidated.

Previous research on a balanced translocation implicated DISC1 in P300 generation in schizophrenia (Blackwood et al., 2001), supported by a recent study of common genetic variation in this gene (Shaikh et

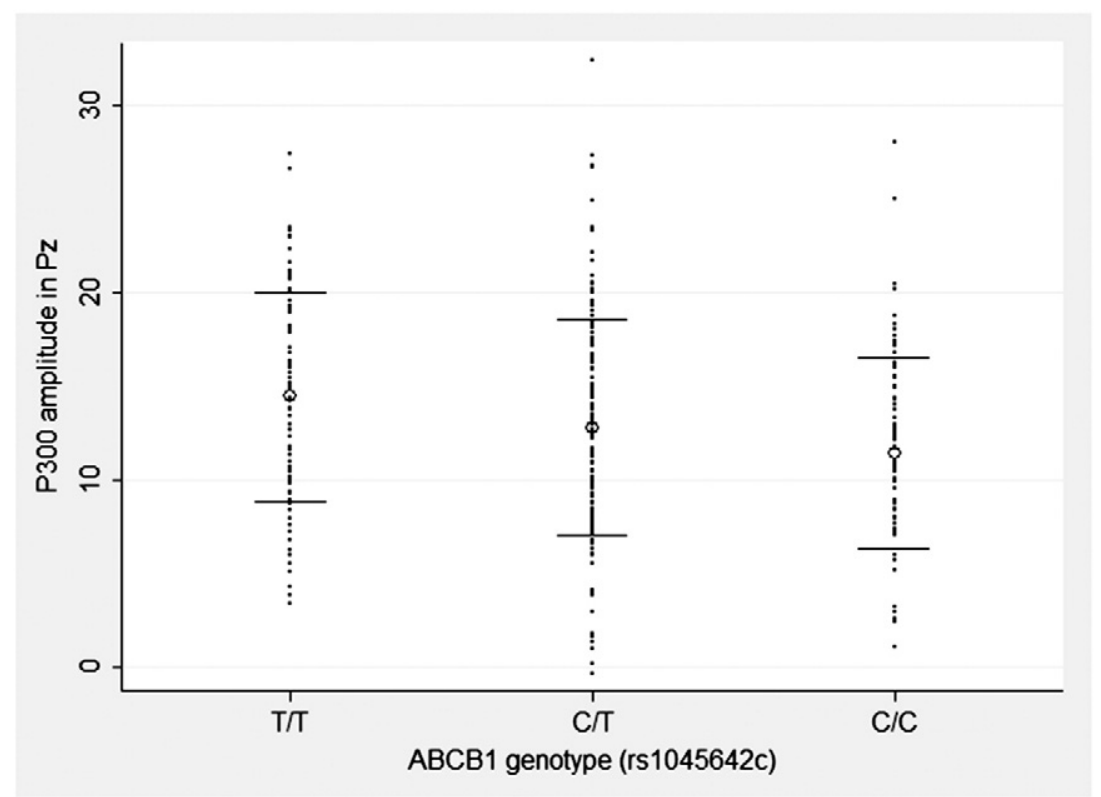

Fig. 1. Scatterplot of $\mathrm{P} 300$ amplitude over ABCB1-genotype. ${ }^{\circ}$ indicates average. Whiskers indicate interval of 1 standard deviation under and above mean. 


\section{Table 3}

Outcome parameters (regression coefficient (coef), standard-error (SE), $p$-value $(p)$ and 95\%-confidence interval (95\%-CI)) of a multiple regression model with P300 amplitude as dependent variable and dummy variables for each class of anti-psychotic medication as independent variables. Number of patients taking each class of anti-psychotics is indicated in the second column $(n)$.

\begin{tabular}{llllll}
\hline Class of anti-psychotic & $n$ & coef & SE & $p$ & 95\%-CI \\
\hline Fenothiazines & 21 & -2.111 & 1.310 & 0.108 & -4.691 to 0.470 \\
Thioxanthenes & 46 & -1.577 & 0.969 & 0.105 & -3.488 to 0.333 \\
Butyrophenones & 28 & 0.833 & 1.223 & 0.496 & -1.576 to 3.242 \\
Diphenylbutylpiperidine & 2 & - & - & - & - \\
Amisulpride & 22 & 1.995 & 1.507 & 0.187 & -0.975 to 4.964 \\
Aripiprazole & 4 & - & - & - & - \\
Clozapine & 25 & 0.246 & 1.433 & 0.864 & -2.576 to 3.069 \\
Olanzapine & 76 & -1.214 & 1.249 & 0.332 & -3.675 to 1.247 \\
Quetiapine & 25 & -1.139 & 1.540 & 0.460 & -4.173 to 1.895 \\
Risperidone & 88 & -.639 & 1.196 & 0.593 & -2.996 to 1.717 \\
\hline
\end{tabular}

al., 2011). The present study may add further weight to this hypothesis, although it should be noted that the associated SNP in this study (rs1572899) did not survive Bonferroni correction for multiple testing, and is not in linkage disequilibrium with rs821597, which was found to be associated with P300 amplitude in the study of Shaikh et al. (2011).

Earlier research has also examined the role of rs6265, better known as BDNF Val66Met, in P300 generation in the general population; Schofield reported a slowed P300 response in Met-homozygotes (Schofield et al., 2009), whereas Hansell failed to find an association between rs6265 and P300 amplitude (Hansell et al., 2007). In this study in schizophrenia patients, the Met-allele was associated with a lower P300 amplitude, although not at the Bonferroni corrected threshold of significance.

Rs1625579 is situated in an intron of a putative primary transcript for microRNA 137 (MIR137), a regulator of neuronal maturation and function. The recent GWAS of Ripke et al. suggested that MIR137 forms part of a newly detected etiological mechanism in schizophrenia (Ripke et al., 2011). Unlike the three other SNPs with a $p$-value $<.01$ in the main analysis, the association between P300 amplitude and rs1625579 was not confirmed in the sensitivity analysis.

Some limitations of this study are worth noting. Although considerable in the light of previous studies, the sample size of 336 patients with a psychotic disorder may have been underpowered to detect more subtle genetic determinants of P300 generation. With the additional sensitivity analysis in 191 patients, lower statistical power was partially compensated by a gain of signal-to-noise ratio. Secondly, the lack of a healthy control sample makes it impossible to draw inferences about the specificity of the findings. However, since P300 is an important intermediate phenotype of schizophrenia, every component explaining some of the individual differences in P300 amplitude may be of significance, as for example, P300 amplitude may help to predict transition in subjects at high risk for developing psychosis (van Tricht et al., 2011). Lastly, since the molecular pathway underlying P300 generation is not fully known, the a priori SNP selection can be questioned. Therefore, future work could use a genome-wide or candidate gene tag-SNP approach to unravel the genetic underpinnings of the P300 generation, but the sample of 336 patients was insufficiently powered to allow for this strategy. Nevertheless, we would argue that the selection in this study harbors most of the relevant SNPs based on the available information and includes SNPs from the classical candidate genes as well as those from genome-wide studies.

Since P300 is one of the most established intermediate phenotypes of schizophrenia, improving the efforts to unravel its genetic underpinnings could be an interesting complementary strategy to increase our understanding of the genetic and biological mechanisms of this disorder.

Supplementary data to this article can be found online at http:// dx.doi.org/10.1016/j.schres.2012.07.018.

\section{Role of funding source}

The SNP-analyses reported in this study were supported by an unrestricted research grant from AstraZeneca.

\section{Contributors}

The study was designed by J Decoster, G Nagels, M De Hert and R van Winkel. W Viechtbauer assisted with the statistical analyses. J Peuskens and G Nagels contributed to the neurophysiological analyses. J Decoster and R van Winkel wrote the first draft of the paper. M De Hert, I Myin-Germeys, J Peuskens and J van Os commented and contributed to the subsequent revisions.

\section{Conflict of interest statement}

None of the authors reported potential conflicts of interest with regard to this manuscript.

Professor De Hert has been a consultant for, received grant/research support and honoraria from, and been on the speakers/advisory boards of Astra Zeneca, Bristol-Myers Squibb, Eli Lilly, Janssen-Cilag, Lundbeck, Pfizer and Sanofi-Aventis. Professor MyinGermeys has received financial compensation as an independent symposium speaker from BMS and Janssen-Cilag. Professor Peuskens has been a consultant for and co-operated in clinical trials with AstraZeneca, Bristol Myers Squibb, Eli Lilly, JanssenCilag, Lundbeck, Pfizer, Sanofi Aventis. He has also received research grants from Astra Zeneca, Janssen-Cilag, Eli Lilly, Lundbeck and Sanofi-Aventis. Professor van Os is/has been an unrestricted research grant holder with, or has received financial compensation as an independent symposium speaker from Eli Lilly, BMS, Lundbeck, Organon, Janssen-Cilag, GSK, AstraZeneca, Pfizer, and Servier. Dr van Winkel has been an unrestricted grant holder with AstraZeneca and Eli Lilly.

\section{Acknowledgements}

The authors thank the electroencephalography technicians of the Neurophysiology Unit of the UPC KULeuven, campus Kortenberg for their assistance in the event-related potentials recordings.

\section{References}

Allen, N.C., Bagade, S., McQueen, M.B., Ioannidis, J.P., Kavvoura, F.K., Khoury, M.J., Tanzi, R.E., Bertram, L., 2008. Systematic meta-analyses and field synopsis of genetic association studies in schizophrenia: the SzGene database. Nat. Genet. 40 (7), 827-834.

Antolin, T., Berman, S.M., Conner, B.T., Ozkaragoz, T.Z., Sheen, C.L., Ritchie, T.L., Noble, E.P., 2009. D2 dopamine receptor (DRD2) gene, P300, and personality in children of alcoholics. Psychiatry Res. 166 (2-3), 91-101.

Berman, S.M., Noble, E.P., Antolin, T., Sheen, C., Conner, B.T., Ritchie, T., 2006. P300 development during adolescence: effects of DRD2 genotype. Clin. Neurophysiol 117 (3), 649-659.

Bestelmeyer, P.E., Phillips, L.H., Crombie, C., Benson, P., St Clair, D., 2009. The P300 as a possible endophenotype for schizophrenia and bipolar disorder: evidence from twin and patient studies. Psychiatry Res. 169 (3), 212-219.

Blackwood, D.H., Fordyce, A., Walker, M.T., St Clair, D.M., Porteous, D.J., Muir, W.J. 2001 Schizophrenia and affective disorders-cosegregation with a translocation at chromosome 1q42 that directly disrupts brain-expressed genes: clinical and P300 findings in a family. Am. J. Hum. Genet. 69 (2), 428-433.

Bonhomme-Faivre, L., Benyamina, A., Reynaud, M., Farinotti, R., Abbara, C., 2008. Disposition of Delta tetrahydrocannabinol in CF1 mice deficient in mdr1a P-glycoprotein. Addict. Biol. 13 (3-4), 295-300.

Bramon, E., McDonald, C., Croft, R.J., Landau, S., Filbey, F., Gruzelier, J.H., Sham, P.C. Frangou, S., Murray, R.M., 2005. Is the P300 wave an endophenotype for schizophrenia? A meta-analysis and a family study. Neuroimage 27 (4), 960-968.

Bramon, E., Dempster, E., Frangou, S., McDonald, C., Schoenberg, P., MacCabe, J.H Walshe, M., Sham, P., Collier, D., Murray, R.M., 2006. Is there an association between the COMT gene and P300 endophenotypes? Eur. Psychiatry 21 (1), 70-73.

Bramon, E., Dempster, E., Frangou, S., Shaikh, M., Walshe, M., Filbey, F.M., McDonald, C., Sham, P., Collier, D.A., Murray, R., 2008. Neuregulin-1 and the P300 waveform-a preliminary association study using a psychosis endophenotype. Schizophr. Res. $103(1-3), 178-185$.

Chen, T.J., Yu, Y.W., Chen, J.Y., Wang, Y.C., Chen, M.C., Hong, C.J., Tsai, S.J., 2002. Association analysis of two dopamine D2 receptor gene polymorphisms and p300 event-related potential in depressive patients. Neuropsychobiology 46 (3), 141-144.

Cordell, H.J., Clayton, D.G., 2005. Genetic association studies. Lancet 366 (9491), 1121-1131.

De Hert, M., Dekker, J.M., Wood, D., Kahl, K.G., Holt, R.I., Moller, H.J., 2009. Cardiovascular disease and diabetes in people with severe mental illness position statement from the European Psychiatric Association (EPA), supported by the European Association for the Study of Diabetes (EASD) and the European Society of Cardiology (ESC). Eur. Psychiatry 24 (6), 412-424.

De Hert, M., van Winkel, R., Silic, A., Van Eyck, D., Peuskens, J., 2010. Physical health management in psychiatric settings. Eur. Psychiatry 25 (Suppl. 2), S22-28.

Gallinat, J., Bajbouj, M., Sander, T., Schlattmann, P., Xu, K., Ferro, E.F., Goldman, D., Winterer, G., 2003. Association of the G1947A COMT (Val(108/158)Met) gene polymorphism with prefrontal P300 during information processing. Biol. Psychiatry 54 (1), 40-48.

Gallinat, J., Gotz, T., Kalus, P., Bajbouj, M., Sander, T., Winterer, G., 2007. Genetic variations of the NR3A subunit of the NMDA receptor modulate prefrontal cerebral activity in humans. J. Cogn. Neurosci. 19 (1), 59-68. 
Golimbet, V., Gritsenko, I., Alfimova, M., Lebedeva, I., Lezheiko, T., Abramova, L., Kaleda V., Ebstein, R., 2006. Association study of COMT gene Val158Met polymorphism with auditory P300 and performance on neurocognitive tests in patients with schizophrenia and their relatives. World J. Biol. Psychiatry 7 (4), 238-245.

Greenwood, T.A., Lazzeroni, L.C., Murray, S.S., Cadenhead, K.S., Calkins, M.E., Dobie, D.J Green, M.F., Gur, R.E., Gur, R.C., Hardiman, G., Kelsoe, J.R., Leonard, S., Light, G.A., Nuechterlein, K.H., Olincy, A., Radant, A.D., Schork, N.J., Seidman, L.J., Siever, L.J., Silverman, J.M., Stone, W.S., Swerdlow, N.R., Tsuang, D.W., Tsuang, M.T., Turetsky, B.I., Freedman, R., Braff, D.L., 2011. Analysis of 94 candidate genes and 12 endophenotypes for schizophrenia from the Consortium on the Genetics of Schizophrenia. Am. J. Psychiatry 168 (9), 930-946.

Hall, M.H., Rijsdijk, F., Picchioni, M., Schulze, K., Ettinger, U., Toulopoulou, T., Bramon, E. Murray, R.M., Sham, P., 2007. Substantial shared genetic influences on schizophrenia and event-related potentials. Am. J. Psychiatry 164 (5), 804-812.

Hall, M.H., Schulze, K., Rijsdijk, F., Kalidindi, S., McDonald, C., Bramon, E., Murray, R.M. Sham, P., 2009. Are auditory P300 and duration MMN heritable and putative endophenotypes of psychotic bipolar disorder? A Maudsley Bipolar Twin and Family Study. Psychol. Med. 39 (8), 1277-1287.

Hansell, N.K., James, M.R., Duffy, D.L., Birley, A.J., Luciano, M., Geffen, G.M., Wright, M.J., Montgomery, G.W., Martin, N.G., 2007. Effect of the BDNF V166M polymorphism on working memory in healthy adolescents. Genes Brain Behav. 6 (3), 260-268.

Hill, S.Y., Locke, J., Zezza, N., Kaplan, B., Neiswanger, K., Steinhauer, S.R., Wipprecht, G. $\mathrm{Xu}, \mathrm{J} ., 1998$. Genetic association between reduced P300 amplitude and the DRD2 dopamine receptor A1 allele in children at high risk for alcoholism. Biol. Psychiatry 43 (1), 40-51.

Johnson, J.P., Muhleman, D., MacMurray, J., Gade, R., Verde, R., Ask, M., Kelley, J Comings, D.E., 1997. Association between the cannabinoid receptor gene (CNR1) and the P300 event-related potential. Mol. Psychiatry 2 (2), 169-171.

Kimchi-Sarfaty, C., Oh, J.M., Kim, I.W., Sauna, Z.E., Calcagno, A.M., Ambudkar, S.V., Gottesman, M.M., 2007. A “silent" polymorphism in the MDR1 gene changes substrate specificity. Science 315 (5811), 525-528.

Liu, J., Kiehl, K.A., Pearlson, G., Perrone-Bizzozero, N.I., Eichele, T., Calhoun, V.D., 2009. Genetic determinants of target and novelty-related event-related potentials in the auditory oddball response. Neuroimage 46 (3), 809-816.

Moons, T., de Roo, M., Claes, S., Dom, G., 2011. Relationship between P-glycoprotein and second-generation antipsychotics. Pharmacogenomics 12 (8), 1193-1211.

Mulert, C., Juckel, G., Giegling, I., Pogarell, O., Leicht, G., Karch, S., Mavrogiorgou, P., Moller, H.J., Hegerl, U., Rujescu, D., 2006. A Ser9Gly polymorphism in the dopamine D3 receptor gene (DRD3) and event-related P300 potentials. Neuropsychopharmacology 31 (6), $1335-1344$.

O'Connor, S., Morzorati, S., Christian, J.C., Li, T.K., 1994. Heritable features of the auditory oddball event-related potential: peaks, latencies, morphology and topography Electroencephalogr. Clin. Neurophysiol. 92 (2), 115-125.

Osborne, J.W., Overbay, A., 2004. The power of outliers (and why researchers should always check for them). Practical Assess. Res. Eval. 9 (6).

Ripke, S., Sanders, A.R., Kendler, K.S., Levinson, D.F., Sklar, P., Holmans, P.A., Lin, D.Y. Duan, J., Ophoff, R.A., Andreassen, O.A., Scolnick, E., Cichon, S., St Clair, D., Corvin, A., Gurling, H., Werge, T., Rujescu, D., Blackwood, D.H., Pato, C.N., Malhotra, A.K., Purcell, S., Dudbridge, F., Neale, B.M., Rossin, L., Visscher, P.M., Posthuma, D., Ruderfer, D.M., Fanous, A., Stefansson, H., Steinberg, S., Mowry, B.J., Golimbet, V. De Hert, M., Jonsson, E.G., Bitter, I., Pietilainen, O.P., Collier, D.A., Tosato, S., Agartz, I., Albus, M., Alexander, M., Amdur, R.L., Amin, F., Bass, N., Bergen, S.E., Black, D.W., Borglum, A.D., Brown, M.A., Bruggeman, R., Buccola, N.G., Byerley, W.F., Cahn, W., Cantor, R.M., Carr, V.J., Catts, S.V., Choudhury, K., Cloninger, C.R., Cormican, P., Craddock, N., Danoy, P.A., Datta, S., de Haan, L., Demontis, D., Dikeos, D., Djurovic, S., Donnelly, P., Donohoe, G., Duong, L., Dwyer, S., FinkJensen, A., Freedman, R., Freimer, N.B., Friedl, M., Georgieva, L., Giegling, I., Gill, M., Glenthoj, B., Godard, S., Hamshere, M., Hansen, M., Hansen, T., Hartmann, A.M., Henskens, F.A., Hougaard, D.M., Hultman, C.M., Ingason, A., Jablensky, A.V., Jakobsen, K.D., Jay, M., Jurgens, G., Kahn, R.S., Keller, M.C., Kenis, G., Kenny, E., Kim, Y., Kirov, G.K., Konnerth, H., Konte, B., Krabbendam, L., Krasucki, R., Lasseter, V.K., Laurent, C., Lawrence, J., Lencz, T., Lerer, F.B., Liang, K.Y., Lichtenstein, P., Lieberman, J.A., Linszen, D.H., Lonnqvist, J., Loughland, C.M., Maclean, A.W., Maher, B.S., Maier, W., Mallet, J., Malloy, P., Mattheisen, M., Mattingsdal, M. McGhee, K.A., McGrath, J.J., McIntosh, A., McLean, D.E., McQuillin, A., Melle, I., Michie, P.T., Milanova, V., Morris, D.W., Mors, O., Mortensen, P.B., Moskvina, V., Muglia, P., Myin-Germeys, I., Nertney, D.A., Nestadt, G., Nielsen, J., Nikolov, I. Nordentoft, M., Norton, N., Nothen, M.M., O'Dushlaine, C.T., Olincy, A., Olsen, L.,
O'Neill, F.A., Orntoft, T.F., Owen, M.J., Pantelis, C., Papadimitriou, G., Pato, M.T., Peltonen, L., Petursson, H., Pickard, B., Pimm, J., Pulver, A.E., Puri, V., Quested, D., Quinn, E.M., Rasmussen, H.B., Rethelyi, J.M., Ribble, R., Rietschel, M., Riley, B.P., Ruggeri, M., Schall, U., Schulze, T.G., Schwab, S.G., Scott, R.J., Shi, J., Sigurdsson, E., Silverman, J.M., Spencer, C.C., Stefansson, K., Strange, A., Strengman, E., Stroup, T.S., Suvisaari, J., Terenius, L., Thirumalai, S., Thygesen, J.H., Timm, S., Toncheva, D., van den Oord, E., van Os, J., van Winkel, R., Veldink, J., Walsh, D., Wang, A.G., Wiersma, D., Wildenauer, D.B., Williams, H.J., Williams, N.M., Wormley, B., Zammit, S., Sullivan, P.F., O'Donovan, M.C., Daly, M.J., Gejman, P.V., 2011. Genome-wide association study identifies five new schizophrenia loci. Nat. Genet. 43 (10), 969-976.

Salisbury, D.F., Shenton, M.E., McCarley, R.W., 1999. P300 topography differs in schizophrenia and manic psychosis. Biol. Psychiatry 45 (1), 98-106.

Schofield, P.R., Williams, L.M., Paul, R.H., Gatt, J.M., Brown, K., Luty, A., Cooper, N., Grieve, S., Dobson-Stone, C., Morris, C., Kuan, S.A., Gordon, E., 2009. Disturbances in selective information processing associated with the BDNF Val66Met polymorphism: evidence from cognition, the P300 and fronto-hippocampal systems. Biol. Psychol. 80 (2), 176-188.

Shaikh, M., Hall, M.H., Schulze, K., Dutt, A., Li, K., Williams, I., Walshe, M., Constante, M. Broome, M., Picchioni, M., Toulopoulou, T., Collier, D., Stahl, D., Rijsdijk, F., Powell, J., Murray, R.M., Arranz, M., Bramon, E., 2011. Effect of DISC1 on the P300 waveform in psychosis. Schizophr. Bull.

Souza, V.B., Muir, W.J., Walker, M.T., Glabus, M.F., Roxborough, H.M., Sharp, C.W., Dunan, J.R., Blackwood, D.H., 1995. Auditory P300 event-related potentials and neuropsychological performance in schizophrenia and bipolar affective disorder. Biol. Psychiatry 37 (5), 300-310.

StataCorp, 2007. Stata/SE Statistical Software, Release 10. StataCorp LP, College Station.

Sullivan, P.F., 2007. Spurious genetic associations. Biol. Psychiatry 61 (10), 1121-1126.

Tsai, S.J., Yu, Y.W., Chen, T.J., Chen, J.Y., Liou, Y.J., Chen, M.C., Hong, C.J., 2003a. Association study of a functional catechol-O-methyltransferase-gene polymorphism and cognitive function in healthy females. Neurosci. Lett. 338 (2), 123-126.

Tsai, S.J., Yu, Y.W., Chen, T.J., Chen, M.C., Hong, C.J., 2003b. Association analysis for dopamine D3 receptor, dopamine D4 receptor and dopamine transporter genetic polymorphisms and P300 event-related potentials for normal young females. Psychiatr. Genet. 13 (1), 51-53.

Turetsky, B.I., Calkins, M.E., Light, G.A., Olincy, A., Radant, A.D., Swerdlow, N.R., 2007. Neurophysiological endophenotypes of schizophrenia: the viability of selected candidate measures. Schizophr. Bull. 33 (1), 69-94.

Umbricht, D.S., Bates, J.A., Lieberman, J.A., Kane, J.M., Javitt, D.C., 2006. Electrophysiological indices of automatic and controlled auditory information processing in first-episode, recent-onset and chronic schizophrenia. Biol. Psychiatry 59 (8), 762-772.

van Beijsterveldt, C.E., van Baal, G.C., Molenaar, P.C., Boomsma, D.I., de Geus, E.J., 2001. Stability of genetic and environmental influences on P300 amplitude: a longitudinal study in adolescent twins. Behav. Genet. 31 (6), 533-543.

van der Stelt, O., Belger, A., 2007. Application of electroencephalography to the study of cognitive and brain functions in schizophrenia. Schizophr. Bull. 33 (4), 955-970.

van Tricht, M.J., Nieman, D.H., Koelman, J.H., van der Meer, J.N., Bour, L.J., de Haan, L Linszen, D.H., 2011. Reduced parietal P300 amplitude is associated with an increased risk for a first psychotic episode. Biol. Psychiatry 68 (7), 642-648.

van Winkel, R., GROUP Investigators, 2011. Family-based analysis of genetic variation underlying psychosis-inducing effects of cannabis: sibling analysis and proband follow-up. Arch Gen Psychiatry 68 (2), 148-157.

van Winkel, R., De Hert, M., Van Eyck, D., Hanssens, L., Wampers, M., Scheen, A., Peuskens, J., 2006. Screening for diabetes and other metabolic abnormalities in patients with schizophrenia and schizoaffective disorder: evaluation of incidence and screening methods. J. Clin. Psychiatry 67 (10), 1493-1500.

van Winkel, R., Rutten, B.P., Peerbooms, O., Peuskens, J., van Os, J., De Hert, M. 2010. MTHFR and risk of metabolic syndrome in patients with schizophrenia. Schizophr. Res. 121 (1-3), 193-198.

Vogel, C.I., Laucht, M., Furtado, E.F., Becker, K., Schmidt, M.H., 2006. Association of DRD4 exon III polymorphism with auditory P300 amplitude in 8-year-old children. J. Neural Transm. 113 (12), 1935-1941.

Wang, Y., Hu, Y., Fang, Y., Zhang, K., Yang, H., Ma, J., Xu, Q., Shen, Y., 2009. Evidence of epistasis between the catechol-O-methyltransferase and aldehyde dehydrogenase 3B1 genes in paranoid schizophrenia. Biol. Psychiatry 65 (12), 1048-1054. 